\title{
Changes in noradrenaline and dopamine levels under oxygen debt conditions in the brain of rats during experimental acute pancreatitis
}

\author{
AGNIESZKA MARKIEWICZ-GOSPODAREK ${ }^{1}$, IWONA ŁUSZCZEWSKA-SIERAKOWSKA ${ }^{1}$, \\ PIOTR KUSZTA ${ }^{2}$, MARCIN KOPIENIAK ${ }^{3}$, ELŻBIETA RADZIKOWSKA-BÜCHNER ${ }^{4}$
}

\author{
1Department of Human Anatomy, Medical University of Lublin, Jaczewskiego 4, 20-090 Lublin, Poland \\ ${ }^{2}$ Students Scientific Association at the Department of Human Anatomy, \\ Medical University of Lublin, Jaczewskiego 4, 20-090 Lublin, Poland \\ ${ }^{3}$ Department of Anesthesiology, Madadeni Hospital, Madadeni Road, Newcastle, 2951, South Africa \\ ${ }^{4}$ Department of Plastic, Reconstructive and Maxillary Surgery, CSK MSWiA, Wołoska 137, 02-507 Warszawa, Poland
}

Markiewicz-Gospodarek A., Łuszczewska-Sierakowska I., Kuszta P., Kopieniak M., Radzikowska-Büchner E. Changes in noradrenaline and dopamine levels under oxygen debt conditions in the brain of rats during experimental acute pancreatitis

\section{Summary}

This study's aim was to assess the level of catecholamines, i.e., noradrenaline and dopamine, under oxygen debt conditions in the brain of experimental animals in which acute pancreatitis was experimentally induced. Catecholamines play the role of neurotransmitters and neuromediators. They are responsible for the regulation of motor and emotional processes, take part in the regulation of hormonal activities, sleep, wakefulness, concentration, attention, and learning processes. The experiment also determined the oxygen tension as an indicator of respiratory failure and the activity of amylase and lipase in the development of the inflammatory process. The animals on which the experiment was conducted were Wistar rats (140 animals) divided into 3 research groups: control $(C)$ animals $(n=30)$, healthy $(H)$ animals $(n=30)$, and operated $(O)$ animals $(n=80)$. The determination of amylase, lipase, oxygen pressure, NA, and DO levels were performed at hours 2 , 6 , 12, 24, and 48 of the experiment. The animals in group $C$ had an injection needle inserted to investigate only the effects of mechanical damage to the organs. On the other hand, the animals in group 0 had a $5 \%$ solution of sodium taurocholate introduced into the common bile-pancreatic duct. The research conducted shows that the most significant changes in NA and DO levels were observed on the first day of the experiment. The concentrations of the above catecholamines were statistically significantly correlated with the level of amylase in the blood. The peak of dopamine was observed between the $6^{\text {th }}$ and $12^{\text {th }}$ hours of the experiment, while the lowest concentration of noradrenaline was observed at the $6^{\text {th }}$ hour of the experiment.

Keywords: acute pancreatitis, catecholamines, brain, rats

Acute pancreatitis (AP) is a common disease that is largely self-limiting and uncomplicated (32). It is defined as a complex of systemic disorders resulting from enzymatic damage to this gland (4). Overall, the incidence of acute pancreatitis continues to increase, and it is one of the most common causes of gastrointestinal hospitalization in the United States, with approximately 300.000 emergency department visits each year (45). For comparison, the number of patients hospitalized for AP in Poland in 2014 was 23.277, including 4.301 with a severe course of the disease (35). AP develops when exocrine cells sustain damage. The consequences of such damage affect mainly men, which may be related to the higher masculine alcohol consumption. The course of the disease may vary in intensity, and the disease often radiates from the upper abdomen to the back (31). In the last decade, significant progress has been made in understanding the pathophysiological mechanisms of pancreatitis (37). Based on the pathomorphological picture according to the Ulm classification, proposed in 1991 by $\mathrm{H}$. Beger and $\mathrm{R}$. Bittner, the following forms of this disease can be distinguished (7):

- interstitial edema pancreatitis - affects $80 \%$ of patients; has a mild course, mortality is low (approx. $1-3 \%$ ), 
- acute necrotizing pancreatitis - affects $10-15 \%$ of patients; sterile and infected necrosis is present,

- pancreatic abscess - occurs more often after alcohol-induced pancreatitis than after non-alcoholinduced pancreatitis (28).

AP is characterized by inflammation of the pancreas, and its natural course can be divided into two phases (27):

- early phase - the systemic in-

flammation reaction syndrome (SIRS) coexists in its course, lasting usually 1-2 weeks,

- late phase-occurs in patients with consequences of AP (fluid accumulation, infection).

Regarding the first form, i.e., interstitial edema pancreatitis, the pancreas and the surrounding tissues are swollen and yellow-green in color. At the same time, there is an accumulation of serous fluid in the peritoneal cavity. The course of this form is mild and, in most cases, ends with recovery.

The second form, i.e., acute necrotizing pancreatitis, is characterized by the presence of non-viable pancreatic parenchyma (3). This organ grows larger and takes on a dark red color, sometimes even black. A fluid the color of "meat washings" collects in the peritoneum. The disease affects the stomach, transverse colon, duodenum, and retroperitoneal space. Changes in the pancreas are correlated with systemic changes and damage to many organs, including the brain (pancreatic encephalopathy)
$(16,23,39)$. Another classification, the so-called Atlanta classification, which includes the morphological and clinical aspects of AP, is presented in Table 1 (9).

Etiology. There are many diseases, factors, and drugs that are known to be responsible for acute pancreatitis directly or indirectly. These factors can be divided into groups as shown in the Figure 1.

Pathogenesis. Improper intracellular activation of proteolytic enzymes causes damage to the pancreas in the presence of intracellular lysozyme enzymes and activation of trypsinogens to trypsin (1). According to classical theory, trypsin is responsible for pancreatic damage and the onset of pathological changes in the organ (53). Trypsin, in turn, activates the cascade of phospholipases, elastases, and other mediators with an increased migration of neutrophils to the pancreas (1). Through its action, factor III I is released from the damaged pancreatic parenchyma. Trypsin itself damages the vascular endothelium, activates prothrombin,



Fig. 1. Factors responsible for acute pancreatitis $(12,17,18,20,21,26,33,34,40,44,48,54)$ 
fibrinogen, and plasminogen, contributing to coagulation disorders and fibrinolysis. ROS (reactive oxygen species) also play an important role in the pathogenesis of AP (54). They are assumed to be responsible for the development of local and systemic inflammatory reactions (49). They are also mediators of cell damage, as they initiate the peroxidation of membrane lipids, thus causing their dysfunction (52). The severity of the disease is due to a disturbed balance between ROS and the body's defense mechanisms. The increased production of free radicals alone is insufficient to induce morphological and enzymatic changes. During $\mathrm{AP}$, a disruption of the balance between thromboxane (TBX2) and prostacyclin (PG12) is observed (59). The increased production of TBX2 contributes to the reduction of blood circulation in the tissues through a strong effect of aggregating platelets and the narrowing of blood vessels (52). Additionally, the increased synthesis of TBX2 impairs the cytoprotective function of prostacyclin (24).

Acute pancreatitis and the brain. From observations of experimental animals, as well as from clinical observations, it appears that changes occurring during AP also affect other organs. The brain is no exception. Symptoms of damage to the central nervous system occur in approximately $30-40 \%$ of patients with AP (22). The occurrence of pancreatic encephalopathy indicates a severe course of the disease. Mortality can be as high as $50 \%$.

Pancreatic encephalopathy was first described in 1923 by Lowell (49). It can lead to a syndrome of neuropsychiatric disorders, which makes it a significant problem for clinicians (50). Many hypotheses try to explain the causes of AP encephalopathy. It is currently believed that changes in the brain may be due to the following mechanisms:

- AP shock,

- DIC (disseminated intravascular coagulation),

- hyperglycemia, hypoglycemia,

- the action of inflammatory mediators,

- consequences of malabsorption from the gastrointestinal tract.

In some of the above disease states, there is a decrease in oxygen delivery to the brain. It is caused by the shock accompanying acute pancreatitis. The cause is blood loss due to hemorrhages, and fluid leakage into the peritoneal cavity. The increase in bradykinin and prostaglandin levels results in vascular dilatation and hypovolemia (37). In shock, the intestinal barrier is damaged due to circulatory disorders, leading to endotoxemia and sepsis. The decrease in oxygen supply may also result from damage to the myocardium before myocardial depressant factor (MDF) is released from the diseased pancreas (58) and the formation of fatty embolisms due to hyperlipidemia that may accompany AP (44). This study aims to assess the level of catecholamines, i.e., noradrenaline and dopamine, under oxygen debt conditions in the brain of experimental animals in which acute pancreatitis was experimentally induced.

\section{Material and methods}

The research was carried out on 140 Wistar rats weighing 240-480 g, with an approval from an ethics committee and in accordance with all animal welfare standards. The animals were divided into 3 groups: control (C) animals $(\mathrm{n}=30)$, healthy $(\mathrm{H})$ animals $(\mathrm{n}=30)$, and operated $(\mathrm{O})$ animals $(n=80), 20$ of which died during the experiment, which constitutes $17 \%$ of the entire group O. An autopsy was not performed, since the underlying disease explained the mortality of the rats. Acute pancreatitis was induced in animals from the operated group $(\mathrm{O})$ by an appropriate method (2). To obtain research material, the animals were anesthetized at 2, 6, 12, 24, and 48 hours after induction. Then the blood was drawn from the left ventricle, and the brains were collected. Between each collection, the animals were sequentially anesthetized and awakened at all intervals. The procedure was performed under sterile conditions, and all animals were subjected to general anesthesia. The rats were administered ketamine $(50-100 \mathrm{mg} / \mathrm{kg}$ bw), and after opening the peritoneal cavity, an injection needle $(0.5 \times 16 \mathrm{~mm})$ was inserted through the duodenum into the common bile-pancreatic duct. The hepatic duct near the hilum was closed with forceps, a ligature was placed at the hepato-pancreatic duct, and a puff suture was placed over the duodenum to avoid reflux of the duodenal contents into the hepato-pancreatic duct. A 5\% sodium taurocholate solution (Sigma, Chemical Co., St. Louis, Missouri) was administered into the common bile-pancreatic duct.

The animals in group $\mathrm{C}$ had an injection needle inserted to investigate only the effects of mechanical damage to the organs. Then, a thoracotomy was performed, and blood

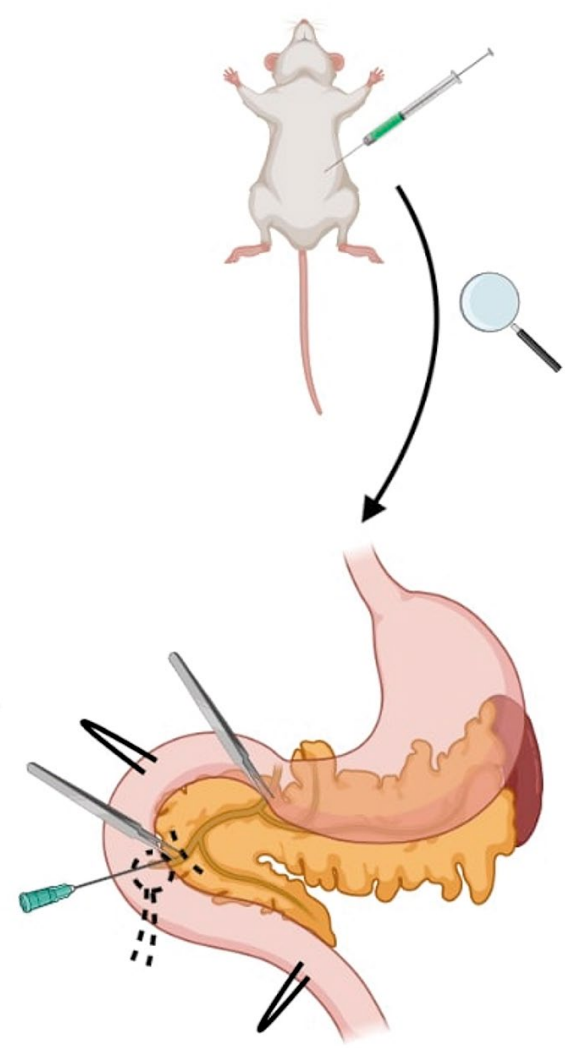

Fig. 2. Schematic illustration of intra-ductal management of a $5 \%$ sodium taurocholate solution for the induction of experimental acute pancreatitis 
was drawn from the left ventricle to determine pancreatic enzyme activity and oxygen tension. Brains were collected for testing to determine the level of biogenic amines. Both hemispheres of the brain were used for biochemical tests. The oxygen pressure was determined with a CIBA Corning 248 analyzer. Amylase activity (EC 3.2.1.1.) was determined by the enzymatic method using Cormay reagents and a Cobas Mira Plus biochemical analyzer. Lipase activity (EC 3.1.1.3.) was determined by turbidimetry using Roche reagents and a Cobas Mira Plus biochemical analyzer. The Chang method modified by Brodie was used to determine the level of noradrenaline (NA) and dopamine (DO) (10, 13). For this purpose, the animal's brain was homogenized in $0.4 \mathrm{~N}$ perchloric acid and centrifuged at $1000 \times$ for 10 minutes. $2 \mathrm{ml}$ of supernatant fluid was added to the tube containing $500 \mathrm{mg}$ of $\mathrm{Al}_{2} \mathrm{O}_{3}$, kept at $\mathrm{pH}$ of 8.2. The above compounds were adsorbed onto $\mathrm{Al}_{2} \mathrm{O}_{3}$ by shaking and eluted with $0.2 \mathrm{~N}$ acetic acid. Then, fluorometric determinations were performed, different for noradrenaline and dopamine. The NA content was determined by measuring the total fluorescence after 60 minutes at a wavelength of $385 / 485 \mu \mathrm{m}$. Dopamine levels were determined by heating the solution to the boiling point of water and measuring the fluorescence after 5 minutes at a wavelength of $320 / 380 \mu \mathrm{m}$.

\section{Results and discussion}

The study assumes that the time points presented in the tables correspond to changes that occur earliest in the human brain (first day), which corresponds to the 2-hour interval in rats, considering their more rapid metabolism. Therefore, marking the $2^{\text {nd }}$ hour interval was used as the starting point.

Table 2 shows amylase (U/dl) values. Amylase activity served as an indicator of the severity of inflammatory changes during AP. In group $\mathrm{H}$, the average value was given, since all values were within the standard deviation. The differences between the values from groups $\mathrm{H}$ and $\mathrm{O}$ and between the values from groups $\mathrm{H}$ and $\mathrm{C}$ were statistically significant in their entirety. The differences between the mean values for groups $\mathrm{O}$ and $\mathrm{C}$ were statistically significant only after the $2^{\text {nd }}$ and $6^{\text {th }}$ hours of the experiment. Amylase activity increased in the subsequent hours, reaching the highest value at the $48^{\text {th }}$ hour of the experiment, both in the control and operated groups.

Table 3 shows lipase values (U/l). Lipase activity was measured to assess the intensity of the inflammatory process. The differences between values from groups $\mathrm{H}$ and $\mathrm{O}$, and between values from groups $\mathrm{H}$ and $\mathrm{C}$ were statistically significant in their entirety. In group $\mathrm{H}$, the average value was given, since all values were within the standard deviation. The differences between values from groups $\mathrm{O}$ and $\mathrm{C}$ were not statistically significant. As in the case of amylase, lipase activity increased in the subsequent hours, reaching a maximum level at the $48^{\text {th }}$ hour of the experiment.

Table 4 shows the oxygen pressure $(\mathrm{mmHg})$. The differences between values from groups $\mathrm{H}$ and $\mathrm{O}$ and between values from groups $\mathrm{H}$ and $\mathrm{C}$ were statistically
Tab. 2. Amylase values (U/dl)

\begin{tabular}{|r|c|c|c|}
\hline Time & $\begin{array}{c}\text { Group H } \\
\text { Average } \pm \text { SD }\end{array}$ & $\begin{array}{c}\text { Group 0 } \\
\text { Average } \pm \text { SD }\end{array}$ & $\begin{array}{c}\text { Group C } \\
\text { Average } \pm \text { SD }\end{array}$ \\
\hline $2 \mathrm{~h}$ & & $486.2 \pm 115.3^{\star}$ & $385.3 \pm 116.3^{*}$ \\
\hline $6 \mathrm{~h}$ & & $721.7 \pm 253.8^{\star}$ & $516.4 \pm 116.7^{\star}$ \\
\hline $12 \mathrm{~h}$ & $292 \pm 74.3$ & $769.3 \pm 276.3^{\star}$ & $784.3 \pm 173.8^{*}$ \\
\hline $48 \mathrm{~h}$ & & $880.7 \pm 238.5^{\star}$ & $808.6 \pm 148.7^{\star}$ \\
\hline
\end{tabular}

Explanations: statistically significant values are marked with an asterisk $(*)$. The differences concern all comparable groups

Tab. 3. Lipase values (U/l)

\begin{tabular}{|c|c|c|c|}
\hline Time & $\begin{array}{c}\text { Group H } \\
\text { Average } \pm \text { SD }\end{array}$ & $\begin{array}{c}\text { Group 0 } \\
\text { Average } \pm \text { SD }\end{array}$ & $\begin{array}{c}\text { Group C } \\
\text { Average } \pm \text { SD }\end{array}$ \\
\hline $2 \mathrm{~h}$ & & $18.1 \pm 3.36^{*}$ & $15.0 \pm 5.4^{*}$ \\
\hline $6 \mathrm{~h}$ & & $19.4 \pm 5.64^{*}$ & $18.1 \pm 7.4^{*}$ \\
\hline $12 \mathrm{~h}$ & $29.8 \pm 15.2$ & $28.9 \pm 15.9^{*}$ & $23.5 \pm 4.8^{*}$ \\
\hline $24 \mathrm{~h}$ & & $140.2 \pm 45.2^{*}$ & $102.9 \pm 31.4^{*}$ \\
\hline $48 \mathrm{~h}$ & & $142.9 \pm 55.9^{*}$ & $135.0 \pm 33.8^{*}$ \\
\hline
\end{tabular}

Explanations: as in Tab. 2.

Tab. 4. Oxygen pressure ( $\mathrm{mmHg})$

\begin{tabular}{|r|c|c|c|}
\hline Time & $\begin{array}{c}\text { Group H } \\
\text { Average } \pm \text { SD }\end{array}$ & $\begin{array}{c}\text { Group 0 } \\
\text { Average } \pm \text { SD }\end{array}$ & $\begin{array}{c}\text { Group C } \\
\text { Average } \pm \text { SD }\end{array}$ \\
\hline $2 \mathrm{~h}$ & $89.42 \pm 4.12$ & $60.48 \pm 1.87^{*}$ & $79.03 \pm 3.15^{*}$ \\
\hline $6 \mathrm{~h}$ & $85.37 \pm 4.41$ & $53.12 \pm 2.38^{*}$ & $74.80 \pm 2.76^{*}$ \\
\hline $12 \mathrm{~h}$ & $87.65 \pm 3.83$ & $51.77 \pm 2.15^{*}$ & $73.30 \pm 1.57^{*}$ \\
\hline $24 \mathrm{~h}$ & $87.54 \pm 4.07$ & $41.18 \pm 2.47^{*}$ & $67.97 \pm 1.11^{*}$ \\
\hline $48 \mathrm{~h}$ & $88.60 \pm 3.78$ & $39.90 \pm 2.97^{*}$ & $66.13 \pm 3.45^{*}$ \\
\hline
\end{tabular}

Explanations: as in Tab. 2.

significant $(p<0.001)$, except for the $2^{\text {nd }}$ hour results from group $\mathrm{C}$.

Table 5 compares the noradrenaline (NA) content in the research groups. NA content in group $\mathrm{O}$ decreased rapidly at the $2^{\text {nd }}, 6^{\text {th }}$, and $12^{\text {th }}$ hours of the experiment. It reached its lowest value at the $6^{\text {th }}$ hour of the experiment and then increased at the $24^{\text {th }}$ and $48^{\text {th }}$ hours. These changes for group $\mathrm{H}$ were statistically significant, excluding the $48^{\text {th }}$ hour. In group C, the NA content correlates similarly. The values obtained were lower than those in group $\mathrm{H}$. The lowest NA level was recorded at the $2^{\text {nd }}$ hour of the experiment. In the subsequent hours, the NA content began to rise. Compared to group $\mathrm{H}$, these changes were statistically significant at the $2^{\text {nd }}$ an $6^{\text {th }}$ hours of the experiment $(p<0.05)$. On the other hand, the differences between groups $\mathrm{O}$ and $\mathrm{C}$ were statistically significant at the $6^{\text {th }}$ and $12^{\text {th }}$ hours. Noradrenaline levels and statistical significance in individual research groups are presented in Table 5.

Table 6 compares the dopamine (DO) content in the research groups. $\mathrm{DO}$ values in group $\mathrm{O}$ were elevated throughout the experiment. These changes were significant at the $6^{\text {th }}$ and $12^{\text {th }}$ hours in comparison with group $\mathrm{H}$. Changes observed in group $\mathrm{C}$ were similar. The increase 
Tab. 5. Content of noradrenaline (NA) $(\mu \mathrm{g} / \mathrm{g})$ in individual study groups

\begin{tabular}{|r|c|c|c|c|c|c|c|c|c|}
\hline \multirow{2}{*}{ Time } & \multicolumn{2}{|c|}{ Group H } & \multicolumn{2}{c|}{ Group 0 } & \multicolumn{2}{c|}{ Group C } & \multicolumn{3}{c|}{ Comparison } \\
& Average \pm SD & Range & Average \pm SD & Range & Average \pm SD & Range & C vs H & O vs H & C vs 0 \\
\hline $2 \mathrm{~h}$ & $399.2 \pm 31.1$ & $346.6-447.4$ & $363.7 \pm 31.1$ & $344.6-394.6$ & $349.8 \pm 18.9$ & $330.5-367.5$ & $\mathrm{p}<0.05^{*}$ & $\mathrm{p}<0.001^{*}$ & $\mathrm{p}>0.05$ \\
\hline $6 \mathrm{~h}$ & $402.4 \pm 33.2$ & $346.6-452.6$ & $316.4 \pm 27.7$ & $259.6-359.6$ & $354.3 \pm 23.4$ & $333.5-385.5$ & $\mathrm{p}<0.05^{*}$ & $\mathrm{p}<0.001^{*}$ & $\mathrm{p}<0.05^{*}$ \\
\hline $12 \mathrm{~h}$ & $391.4 \pm 27.5$ & $342.6-436.6$ & $329.0 \pm 18.6$ & $308.6-356.6$ & $363.0 \pm 21.7$ & $334.5-380.5$ & $\mathrm{p}>0.05$ & $\mathrm{p}<0.001^{*}$ & $\mathrm{p}<0.05^{*}$ \\
\hline $24 \mathrm{~h}$ & $396.0 \pm 26.8$ & $339.6-436.6$ & $365.3 \pm 37.0$ & $334.4-428.4$ & $378.9 \pm 12.7$ & $370.5-393.5$ & $\mathrm{p}>0.05$ & $\mathrm{p}<0.05^{*}$ & $\mathrm{p}>0.05$ \\
\hline $48 \mathrm{~h}$ & $396.2 \pm 26.4$ & $342.6-442.6$ & $403.4 \pm 29.9$ & $370.4-451.4$ & $390.9 \pm 7.2$ & $372.5-385.2$ & $\mathrm{p}>0.05$ & $\mathrm{p}>0.05$ & $\mathrm{p}>0.05$ \\
\hline
\end{tabular}

Explanations: value of significance levels for all research groups considering statistically significant values $(*)$. The differences concern all comparable groups

Tab. 6. Content of dopamine (DO) $(\mu \mathrm{g} / \mathrm{g})$ in individual study groups

\begin{tabular}{|r|c|c|c|c|c|c|c|c|c|}
\hline \multirow{2}{*}{ Time } & \multicolumn{2}{|c|}{ Group H } & \multicolumn{2}{c|}{ Group 0 } & \multicolumn{2}{c|}{ Group C } & \multicolumn{3}{c|}{ Comparison } \\
& Average \pm SD & Range & Average \pm SD & Range & Average \pm SD & Range & C vs H & O vs H & C vs 0 \\
\hline $2 \mathrm{~h}$ & $446.9 \pm 61.6$ & $346.4-543.1$ & $492.3 \pm 11.6$ & $480.1-508.1$ & $456.3 \pm 34.1$ & $401.5-505.5$ & $\mathrm{p}<0.05^{*}$ & $\mathrm{p}>0.05$ & $\mathrm{p}<0.05^{*}$ \\
\hline $6 \mathrm{~h}$ & $445.4 \pm 63.6$ & $333.4-543.1$ & $504.4 \pm 30.5$ & $476.1-534.1$ & $494.7 \pm 15.7$ & $476.5-518.5$ & $\mathrm{p}<0.05^{*}$ & $\mathrm{p}<0.05^{*}$ & $\mathrm{p}>0.05$ \\
\hline $12 \mathrm{~h}$ & $456.9 \pm 56.2$ & $365.4-562.1$ & $493.3 \pm 13.6$ & $482.1-513.1$ & $510.4 \pm 32.8$ & $482.5-563.5$ & $\mathrm{p}>0.05$ & $\mathrm{p}<0.05^{*}$ & $\mathrm{p}<0.05^{*}$ \\
\hline $24 \mathrm{~h}$ & $447.4 \pm 62.5$ & $346.4-549.1$ & $498.1 \pm 1.5$ & $497.1-500.1$ & $478.1 \pm 33.5$ & $439.0-516.5$ & $\mathrm{p}<0.05^{*}$ & $\mathrm{p}>0.05$ & $\mathrm{p}>0.05$ \\
\hline $48 \mathrm{~h}$ & $446.7 \pm 63.1$ & $340.1-547.1$ & $494.4 \pm 18.9$ & $481.1-516.1$ & $491.5 \pm 29.5$ & $458.5-524.5$ & $\mathrm{p}>0.05$ & $\mathrm{p}>0.05$ & $\mathrm{p}>0.05$ \\
\hline
\end{tabular}

Explanations: as in Tab. 5.

in the DO content was maintained throughout the duration of the experiment. Regarding group $\mathrm{H}$, these differences were statistically significant at the $2^{\text {nd }}, 6^{\text {th }}$, and $24^{\text {th }}$ hours of the experiment $(p<0.05)$. The differences between groups $\mathrm{O}$ and $\mathrm{C}$ were statistically significant at the $2^{\text {nd }}$ and $12^{\text {th }}$ hours of the study. Dopamine levels and statistical significance in individual research groups are presented in Tab. 6 .

Encephalopathy is a condition that causes changes in the noradrenergic and dopaminergic systems, as well as changes related to the distribution of catecholamines (15). This type of modification occurs during acute pancreatitis, liver failure, and sepsis $(25,47)$.

In this study the disease state associated with pancreatitis was induced by the Heinkel and Aho method, resulting in a condition similar to the natural disease process in which necro-hemorrhagic changes are the dominant signs $(11,57)$. The experiment in rats confirmed similar changes seen in humans (2), including systemic changes caused by AP. Undoubtedly, the changes are influenced by comorbidities, but the experiment confirmed that the level of neurotransmitters is significantly modified after the $2^{\text {nd }}$ hour of the experiment in the case of noradrenaline, and the $6^{\text {th }}$ hour in the case of dopamine. The material from the groups analyzed shows that in the groups of healthy $(\mathrm{H})$ and operated $(\mathrm{O})$ animals, the greatest decrease was observed in the $6^{\text {th }}$ hour of the experiment in the operated $(\mathrm{O})$ rats. In the following hours, these levels decreased, reaching their minimum on the second day. This was confirmed by Baraldi, Hadesman and McKinzie $(5,29,45)$ in their studies on damaged livers. On the other hand, Mans and Simert $(42,56)$ showed opposite changes, which did not confirm reduction in the values analyzed.
Cuilleret et al. (19) conducted a similar experiment in humans with liver failure and advanced encephalopathy. The researchers did not confirm the relationship between the level of catecholamines and the abovementioned diseases. In their opinion, encephalopathy is not secondary to changes in the catecholamine content in the brain. This may indicate differences in the pathogenesis of the CNS (Central Nervous System) itself. It should be added that a damaged endocrine pancreas causes several biochemical changes, such as a change in the glucose level, lactic acidosis accompanied by brain edema, and damage to GABAergic neurons. These changes, in turn, cause vascular embolism and consequently hypoxia of the CNS. The experiment also confirmed statistically significant changes in the level of dopamine in both groups (healthy and operated), which increased in the $2^{\text {nd }}$ hour of the experiment, reaching its peak at the $12^{\text {th }}$ hour. The result obtained was consistent with data from an experiment by Hadesmand and McKinzie $(29,45)$. Similar results were also obtained by Bhetii and Chang $(6,14)$, who additionally analyzed the release of the substance $P$ responsible for the release of dopamine in the caudate nucleus (36). As in the case of noradrenaline, there are publications that do not confirm the increase in dopamine levels during $\operatorname{AP}(5,8,42)$. Undoubtedly, comorbidities (sepsis, pulmonary inflammation, brain edema) cause changes in the level of neurotransmitters that affect the biochemical response of the body, including hypoxia, which was confirmed by the present experiment. This study partially confirms other researchers' analyses related mainly to the AP picture and the accompanying changes. Nevertheless, they certainly need to be extended to include comorbid somatic, traumatic, or neurological diseases. 


\section{References}

1. Al Mofleh I. A.: Severe acute pancreatitis: pathogenetic aspects and prognostic factors. World J. Gastroenterol. 2008, 14, 675-684

2. Aho H. J., Koskensalo S. M. L., Novalainen T. J.: Experimental pancreatitis in the rat: Sodium taurocholate-induced acute hemorrhagic pancreatitis. Scand. J. Gastroenterol. 1980, 15, 411-416.

3. Arvenitakis M., Ducomonceau J.-M., Albert J., Badaoui A., Bali M. A., Barthet M., Basselink M., Deviere J., Ferreira A. O., Gyokeres T., Hritz I., Hucl T., Milashka M., Papanikolaou I. S., Pley J.-W., Seewald S., Vanbiervliet G., van Lienden K., van Santvoort H., Voermans R., Delhaye M., van Hooft J. Endoscopic management of acute necrotizing pancreatitis: European Society of Gastrointestinal Endoscopy (ESGE) evidence-based multidisciplinary guidelines. Endoscopy 2018, 50, 524-546.

4. Baj J., Radzikowska E., Maciejewski M., Dabrowski A., Torres K.: Prediction of acute pancreatitis in the earliest stages - role of biochemical parameters and histopathological changes. Pol. Przegl. Chir. 2017, 89, 31-38.

5. Baraldi M., Zeneroli M. L., Ricci P., Caselgrandi E., Ventura E.: Down regulation of striatal dopamine receptors in experimental hepatic encephalopathy. Life Sci. $1983,32,1417$

6. Bathia M., Neoptolemos J. P., Salvin J.: Inflammatory mediators as therapeutic targets in acute pancreatitis. Curr. Opin. Investig. Drugs. 2001, 2, 496-501

7. Beger H. G., Rau B., Mayer J., Pralle U.: Natural course of pancreatitis. World J. Surg. 1997, 21, 130-135.

8. Bergeron M., Reader T. A., Layrargues G. P., Butterworth R. F.: Monoamines and metabolites in autopsied brain tissue from cirrhotic patients with hepatic encephalopathy. Neurochem. Res. 1989, 14, 853-859.

9. Bradley E. L.: A clinically based classification system for acute pancreatitis. Summary of the international symposium on acute pancreatitis. Arch. Surg. 1993, 128, 568-590.

10. Brodie B. B., Comer M. S., Costa E., Dlabac A.: The role of brain serotonin in the central action of reserpine. J. Pharmacol. Exp. Ther. 1966, 152, 340-349.

11. Brown T. T., Prahlow J. A.: Postmortem serum amylase and lipase analysis in the diagnosis of acute pancreatitis. Academic Forensic Pathology 2018, 8, 311-323.

12. Cicalese L., Sahai A., Sileri P., Rastellini C., Subbotin V., Ford H., Lee K.: Acute pancreatitis and bacterial translocation. Digestive Diseases and Sciences 2001 , 46, 1127-1132.

13. Chang C. C.: A sensitive method for spectrophotofluorometric assay of catechol amines. Int. J. Neuropharmacol. 1964, 3, 643-649.

14. Chang C. C.: Neurotransmitter amines in brain edema of a rat glioma model. Neurol. Med. Chir. (Tokyo) 1989, 29, 187-191.

15. Chen R., Wang J., Yu Ch.: Correlation study between the expression of dopamine receptor in brain and the pancreatic encephalopathy. Journal of Practical Medicine 2017, 33, 3012-3016.

16. Congard P., Meunier M., Ferry C.: Colonic complications of acute pancreatitis, apropos of 4 cases. Ann. Chir. 1988, 42, 7-10.

17. Criddle D. N.: The role of fat and alcohol in acute pancreatitis: A dangerous liaison. Pancreatology 2015, 12, 6-12.

18. Cruz-Monserrate Z., Conwell D. L., Krishna S. G.: The impact of obesity on gallstone disease, acute pancreatitis and pancreatic cancer. Gastroenterology Clinics 2016, 45, 625-637.

19. Cuilleret G., Pomier-Layrargues G., Pons F., Cadilhac J., Michel H.: Changes in brain catecholamine levels in human cirrhotic hepatic encephalopathy. Gut 1980, 21, 565-569.

20. Dairi S., Demeusy A., Sill A. M., Patel S. T., Kowdley G. C., Cunningham S. C. Implications of gallbladder cholesterolosis and cholesterol polyps. Journal of Surgical Research. 2016, 200, 467-472.

21. Dickson A. P., O'Neil J., Imrie C. W.: Hyperlipidemia, alcohol abuse and acute pancreatitis. Pr. J. Surg. 1984, 71, 685-688.

22. Farkas G., Morton J., Nagy Z., Mandi Y., Takacs T., Deli M. A., Abraham C. S. Experimental acute pancreatitis results in increased blood-brain barrier permeability in the rat: a potential role for tumor necrosis factor and interleukin 6 . Neurosci-Lett. 1998, 242, 147-150.

23. Feig B. W., Pomerantz R. A., Vogenlzang R.: Treatment of peripancreatic fluid collection in patients with complicated acute pancreatitis. Surg. Gynec. Obstetr. 1992, 175, 429-436.

24. Fomela R. J., Galloway S. W., Kingsnorth A. N.: Inflammatory mediators in acute pancreatitis. Brit. J. Surg. 1995, 82, 6-10.

25. Freud H. R., Muggia-Sullam M., Peiser J., Melamed E.: Brain neurotransmitter profile is deranged during sepsis and septic encephalopathy in the rat. J. Sug. Res. 1985, 38, 267-271.

26. Frey Ch. F. Classification of acute pancreatitis. Int. J. Pancreatol. 1991, 9, 39-49.

27. Gad M. M., Simons-Linares C. R.: Is aggressive intravenous fluid resuscitation beneficial in acute pancreatitis? A meta-analysis of randomized control trials and cohort studies. World J. Gastroeneterol. 2020, 26, 1098-1106.

28. Habashi S., Draganov P. V: Pancreatic pseudocyst. World J. Gastroeneterol. $2009,15,38-47$

29. Hadesman R., Wiesner R. H., Go V. L., Tyce G. M.: Concentrations of 3,4-dihydroxyphenylalanine and catecholamines and metabolites in brain in an anhepatic model of hepatic encephalopathy. J. Neurochem. 1995, 65, 417-421.
30. Hoilat G. J., Katta S.: Pancreatic abscess. StatPearls 2021.

31. Iha R. K., Ma Q., Sha H., Palikhe M.: Acute pancreatitis: a literature review. Med. Sci. Monit. 2009, 15, 147-156.

32. Ioannidis $O$. ., Lavrentieva A., Botsios D.: Nutrition support in acute pancreatitis J. Pancreas. 2018, 9, 375-390.

33. Kelly T. R.: Gallstone pancreatitis. The timing of surgery. Surgery 1980, 88, 345-349.

34. Kota S. K., Krishna S. V. S., Lakhtakia S., Modi K. D.: Metabolic pancreatitis: etiopathogenesis and management. Indian J. Endocrinol. Metab. 2013, 17, 799$-805$

35. Koziet D., Gluszek S.: Epidemiology of acute pancreatitis in Poland - selected problems. Medical Studies. 2016, 32, 1-3.

36. Krasnova I. N. Bychkov E. R., Lioudyno V. I., Zubareva O. E., Dambinova $S$. A.: Intracerebroventricular administration of substance P increases dopamine content in the brain of 6-hydroxydopamine-lesioned rats. Neuroscience 2000 95, 113-117.

37. Kruse P., Hage E., Lasson A.: Proteases and proteases inhibitors in taurocholateinduced acute pancreatitis in rats. Int. J. Pancreatol. 1999, 25, 113-121.

38. Lee P. J., Papachristou G. I.: New insights into acute pancreatitis. Nature Reviews Gastroenterology \& Hepatology 2019, 16, 479-496.

39. Lv Y., Jing G., Zhu G., Luo H., Li B., Xie Y., Li C., Wang X.: Effect and mechanism of etanercept on pancreatic encephalopathy. Molecular Medicine Reports 2020 2615-2623.

40. Maciejewski R., Burski K., Baj J., Madej B., Burdan F., Dąbrowski A., Brakowiecki F.: Changes in pancreatic lysosomal enzymes activity as the potential factors leading to diabetic enteropathy. Journal of Physiology and Pharmacology 2001, 52, 823-834

41. Madej B., Burdan F. Dudka J., Radzikowska E., Euszczewska-Sierakowska I. Poznański P., Ciechanek R., Prażmo W., Maciejewski R.: Rola dootrzewnowego podawania soli fizjologicznej w leczeniu ostrego zapalenia trzustki. Med. Weter. 2006, 62, 1443-1445

42. Mans A. M., Consevage M. W., DeJoseph M. R., Hawkins R. A.: Regional brain monoamines and their metabolites after portacaval shunting. Metab. Brain Dis 1987, 2, 183-193.

43. Mans A. M., Hawkins R. A.: Brain monoamines after portacaval anastomosis Metab. Brain Dis. 1986, 1, 45-52.

44. Mayren J.: Acute pancreatitis. Pathogenetic factors as a basis for treatment Scand. J. Gastroenterol. 1997, 12, 513-517.

45. McKinzie S. L., Hammond D. L., Grabau C., Tyce G. M.: Releases of norepinephrine and dopamine in ventriculocisternal perfusions in hepatectomized and laparotomized rats. J. Neurochem. 1996, 66, 569-578.

46. Mederos M. A., Reber H. A., Girgis M. D.: Acute pancreatitis. JAMA Network 2021, 325, 382-390.

47. Michalak A., Rose C., Butterworth R. F.: Loss of noradrenaline transporter sites in frontal cortex of the rats with acute (ischemic) liver failure. Neurochem Int 2001, 38, 25-30.

48. Mikolasevic I., Milic S., Orlic L., Poropat G., Jakopcic I., Franjic N., Klanac A., Kristo N., Stimac D.: Metabolic syndrome and acute pancreatitis. European Journal of Internal Medicine 2016, 32, 79-83.

49. Mittal S. H., Mittal S., Govil T.: The uncommon syndrome of pancreatic encephalopathy. Astrocyte 2016, 2, 185-186.

50. Park B. K., Chung J. B., Lee J. H., Suh J. H., Park S. W., Song S. Y., Kim H., Kim $K$. H., Kang J. K.: Role of oxygen free radicals in patients with acute pancreatitis. World J. Gastroenterol. 2003, 9, 2266-2269.

51. Qian N.-S., Xu X.-P., Chen Y, Dou K.-F, Wang Y.-Y, Yang $Y-L$.: Protective effect of cyclosporin A on brain injury in rats with acute necrotic pancreatitis. Life Sciences 2010, 87, 64-68.

52. Rau B., Poch B., Gansauge F., Bauer A., Nussler A. K., Nevalainen T., Schoenberg M. H., Beger H. G.: Pathophysiologic role of oxygen free radicals in acute pancreatitis. Ann. Surg. 2000, 231, 352-360.

53. Schmidt H., Creutzfeldt $W$.: Role of enzyme activation in the pathogenesis of pancreatitis. Tij. Gastroenterol. 1969, 32, 77-85.

54. Schoenberg M. H., Buchler M., Gaspar M., Stinner A., Younes M., Melzner I., Bultmann B., Beger H. G.: Oxygen free radicals in acute pancreatitis of the rat. Gut. 1990, 31, 1138-1143.

55. Sharbidre K. G., Galgano S. J., Morgan D. E.: Traumatic pancreatitis. Abdominal Radiology 2020, 45, 1265-1276.

56. Simert G., Mobin A., Rosengren E., Vang J.: Neurotransmitter changes in rat brain after portacaval anastomosis. Eur. Surg. Res. 1978, 10, 73-85.

57. Swarhib M. S., Faridah M. N., Tan L. J., Tan R. Z.: A sudden death after the complaint of constipation - not to overlook pediatric acute hemorrhagic pancreatitis. Int. Med. J. 2018, 25, 263-265.

58. Yegneswaran B., Kostis J. B., Pitchumoni C. S.: Cardiovascular manifestations of acute pancreatitis. Journal of Critical Care 2011, 26, 225.e11-225.e18.

59. Zhou W., Levine B. A., Olson M. S.: Lipid mediator production in acute and chronic pancreatitis in the rat. Journal of Surgical Research 1994, 56, 37-44.

Corresponding author: Agnieszka Markiewicz-Gospodarek, DVM, Jaczewskiego 4, 20-090 Lublin, Poland; e-mail: agnieszkamarkiewiczgospodarek@umlub.pl 